\title{
Strategic linkage process and value-driven system: A dynamic analysis of high-tech firms in a newly-industrialized country
}

\author{
Hao-Chen Huang ${ }^{\mathrm{a}, *}$, Wenyi Chu ${ }^{\mathrm{a}}$, Mei-Chi Lai ${ }^{\mathrm{b}}$, Lee-Hsuan Lin $^{\mathrm{c}}$ \\ ${ }^{a}$ Graduate Institute of Business Administration, National Taiwan University, College of Management Floor 9, No.1, Section 4, Roosevelt Road, Taipei 106, Taiwan, ROC \\ ${ }^{\mathrm{b}}$ Graduate Institute of Health Care Organization Administration, National Taiwan University, 6F., No. 17, Syujhou Road, Taipei 100, Taiwan, ROC \\ ${ }^{\mathrm{c}}$ Department of Accounting, Yuan-Ze University, No. 135, Yuan-Tung Road, Chung-Li, Taoyuan 320, Taiwan, ROC
}

\section{A R T I C L E I N F O}

\section{Article history:}

Available online $\mathrm{xxxx}$

\section{Keywords:}

Balanced scorecard

Lagging measurement

Leading measurement

Time-lag effect

\begin{abstract}
A B S T R A C T
The current balanced scorecard literature suggests that a link should exist between lagging and leading measurements of non-financial performance perspectives and financial performance measures. This work designed a dynamic integrated model for examining the influence of strategic links on the Taiwanese high-tech industry, and to examine the relationships among the strategic perspectives of the balanced scorecard (BSC). This work studied the descriptive validity of the balanced scorecard as a causal model for leading and lagging measurements of non-financial and financial performance in relation to timelag effects. Structural equation modeling (SEM) and dynamic analysis were used to empirically examine the relations among strategic linkages and value drivers within the model. The analytical results demonstrate the existence of directly positive driver effects between the learning-growth, customer, and financial perspectives; also the internal process (leading measurements) mediates the relationship between learning-growth (leading measurements) and financial perspective (lagging measurements). The results indicated that time tag positively influenced the non-financial and financial perspectives, and that they were strongly correlated with the strategic linkage process.
\end{abstract}

(c) 2008 Elsevier Ltd. All rights reserved.

\section{Introduction}

The high-tech industry is a fastest growing industry in many newly-industrialized countries (NICs) such as Taiwan, Korea, and India. Taiwanese government has viewed the high-tech industry as a driver of economic growth, and used various resources to support its development, including building the Hsin-chu Sciencebased Industrial Park and legislating the "Statute for Encouraging Investment" and the "Statute for Upgrading Industry" (Chen \& Huang, 2004; Chen, Wu, \& Lin, 2006; Shyu \& Chiu, 2002; Wu, Hung, \& Lin, 2006). Furthermore, the Ministry of Economic Affairs (MOEA) launched technology development programs to accelerate the development of industrial innovation technology and to stimulate domestic economic growth in Taiwan. Since the early 1980s, the active involvement of the government and private enterprises in developing the electronic information and high-tech industries has yielded excellent results. The high-tech industry has grown rapidly and become a significant industrial sector in Taiwan, with a sharply increasing number of firm establishments (Tseng \& Goo, 2005). Furthermore, during the past decades, globalization

\footnotetext{
* Corresponding author. Tel.: +886 2 33661058; fax: +886 223625379 .

E-mail addresses: d94741004@ntu.edu.tw (H.-C. Huang), wenyichu@management. ntu.edu.tw (W. Chu), d94843004@ntu.edu.tw (M.-C. Lai), Islin@saturn.yzu.edu.tw (L.-H. Lin).
}

has enhanced global competition and placed considerable pressures for multinational corporations to lower costs and to increase efficiency as well as profitability. Consequently, many multinational corporations shifted some of their manufacturing and design activities abroad and performed strategic outsourcing in Taiwan. Taiwan was chosen mainly because of its combination of low manufacturing costs, skillful work forces, and tax breaks provided by the local government (Hu \& Schive, 1998). Furthermore, high-tech firms that realize economies of location by dispersing each of its value creation activities to the optimal location for that activity should enjoy a competitive advantage over a firm that bases all of its value creation activities at a single location (Hu \& Schive, 1998).

The electronics, information and high-tech industries in Taiwan are dominated by OEM/ODM (original equipment manufacturing/ original design manufacturing) manufacturers, and firms in these industries face dynamic changes in terms of technological environment and market competition. Given the growing challenges and competition from local and international environments, domestic high-tech firms must adopt appropriate strategies to enhance their competitive advantages and profitability, and the issue of how to drive the performance of high-tech firms has thus become increasingly important in Taiwan.

During the past decade academicians and researchers in strategic management and managerial accounting areas have devoted increasing attention to the influence of non-financial measurements 
on financial performance (Banker, Chang, \& Pizzini, 2004; Banker, Potter, \& Srinivasan, 2000). The balanced scorecard developed by Kaplan and Norton (1992) uses a sequence of four perspectives that reflects the value creation activities of firms. The sequence begins with the learning and growth perspective, followed by the internal/business process, then the customer perspective in third place, and finally the financial perspective. Core outcome (performance) measures within each perspective are taken as leading indicators of the core outcome measures in the next perspective. Kaplan and Norton argued for the existence of a secondary set of associations besides the links among the four balanced scorecard perspectives (Kaplan \& Norton, 1993, 1996a, 1996b, 1996c, 2001a, 2001b, 2001c, 2001d, 2004a, 2004b, 2004c, 2004d, 2006). Within each of the four perspectives of the BSC, performance drivers (performance measures) are expected to be the leading indicators of core outcome measures. The BSC view of the firm indicates that strategic linkages and value drivers provide firms with competitive advantages and improved performance. Since being developed by Kaplan and Norton, the BSC concept has been widely adopted by manufacturing and service companies, nonprofit organizations, government entities, and other industries around the world. A considerable number of research has employed the BSC concept to study the performance of manufacturing firms and manufacturing strategies, for example Blundell, Sayers, and Shanahan (2003); Bryant, Jones, and Widener (2004); Duh, Chow, and Chen (2006); Fernandes, Raja, and Whalleyc (2006); Hoque and James (2000); Huang, Lee, and Kao (2006); Knotts, Jones, and Udell (2006); Lee, Chen, and Chang (2008); Maltz, Shenhar, and Reilly (2003); Sohn, You, Lee, and Lee (2003).

Based on the existing literature, this work has three aims: (a) to examine the relationships between non-financial measurements and financial performance; (b) to examine the relationships between lagging and leading measurements; and (c) to present a conceptual framework for linking non-financial measurements and financial performance regarding time-lag effects (that is, the dynamic BSC framework). By using the structural equation model (SEM) as the analytical tool, this work attempted to answer the following questions: (a) How do learning/growth and internal/business process drive the customer and financial perspectives in the high-tech industry? (b) What are the relationships between lagging and leading measurements? (c) How do time-lag effects influence value creation and organizational performance (that is, customer and financial performance)? (d) How do high-tech firms translate their learning/growth perspective into increased financial performance, whether in terms of productivity, increased growth sales, product acceptance rate, or other organizational performance indicators? This research thus attempts to enhance understandings of how and to what extent the time-lag effect influences the dynamic BSC framework.

The structure of this paper is organized as follows. Section 2 briefly reviews the BSC theory and summarizes the theoretical foundations of the research, with two sets of hypotheses developed. The conceptual framework of the research is then presented in Section 3, along with the research methodology, including the instrument, samples, variables and analytic models. Section 4 then described the empirical analysis methods, including correlation and SEM analyses, followed by the empirical results; a framework of dynamic BSC framework was then developed. Finally, summary, practical implications and suggestions for future research conclude this paper.

\section{Literature and hypotheses}

\subsection{The balanced scorecard and hypotheses development}

First described by Kaplan and Norton in 1992, the balanced scorecard approach comprises four perspectives: the learning and growth perspective, internal process perspective, customer perspective, and financial perspective. BSC is a strategic approach and performance management system which organizations can use to implement their vision and strategy. The BSC model comprises four new management processes that, separately and in combination, contribute to linking long-term strategic objectives with short-term actions (Kaplan \& Norton, 1996a). Numerous companies and industries have adopted the balanced scorecard, which appears to meet several management needs. The BSC model is more than a collection of financial and non-financial measurements; it is a translation of business unit strategy into a linked set of measures that define both long-term strategic objectives and the mechanisms for achieving and obtaining feedback regarding those objectives (Kaplan \& Norton, 1996a). Kaplan and Norton (2004a) created a powerful new tool, the strategy map, with which companies can describe the links between intangible assets and value creation with a previously impossible degree of clarity and precision. The strategy map can be used to link processes with desired outcomes; to evaluate, measure, and improve the processes most critical to success; and to target investments in human, informational, and organizational capital (Kaplan \& Norton, 2004a, 2004b).

The BSC model identifies four related perspectives on activities that may be critical to almost all organizations and all levels within organizations: (a) Investing in learning and growth capabilities, (b) Improving internal process efficiencies, (c) Providing customer value, and (d) Increasing financial success (Kaplan \& Norton, 1992, 1993, 1996a, 1996b, 1996c, 2001a, 2004b).

According to Kaplan and Norton (1992, 1996b), a strategy is a set of hypotheses regarding cause and effect, and three issues need to be considered: (1) cause-and-effect relationships; (2) result measurements and performance-driven factors; and (3) combination with finance.

(1) Cause-and-effect relationships. An identifiable causal relation is important to the balanced scorecard approach in selecting appropriate indicators because it enables the translation of financial objectives. By assessing the relevant factors in each segment of the balanced scorecard that may impact a financial target, appropriate measures can be identified and actions can be aligned to the strategic goals.

(2) Result measurement and performance-driven factors. During the design of the BSC model, the combination of leading indicators as performance-driven factors and lagging indicators as result measurements is used to monitor firm shortterm operations and long-term growth.

(3) Combination with finance. The cause-and-effect relationships of the BSC indicators should be clearly linked to the financial targets of firms.

The BSC model assumes a causal relationship among four perspectives: measures of learning and growth, measures of internal processes, measures of customer perspectives, and financial measures. The assumption of a causal relationship and strategic linkage process is essential because it permits firms to use non-financial performance measurements to forecast future financial performance. Based on the related theory and research, five hypotheses are thus developed. These hypotheses are testable given the development of appropriate lagging (outcome) measures and leading measures. Consequently, the following hypotheses are developed:

H1a. There exists a positive relation between the learning-growth and the internal process perspectives.

H1b. There exists a positive relation between the learning-growth and financial perspectives.

H1c. There exists a positive relation between the learning-growth and customer perspectives. 
H2a. There exists a positive relation between the internal process and financial perspectives.

$\mathrm{H} 2 \mathrm{~b}$. There exists a positive relation between the internal process and customer perspectives.

\subsection{Strategic linkage process and value drivers}

According to Kaplan and Norton (1992), the BSC model was originally defined and designed as a framework to facilitate the translation of business strategy into strategic performance measures, and the core outcome (performance) measures within each perspective are assumed to be the leading indicators of the core outcome measures in the next perspective. During the past decade researchers interested in balanced scorecard argued that the BSC model is an effective tool for communication and helps achieve strategic alignment. The BSC model facilitates the alignment of people and processes with organizational strategy (Kaplan \& Norton, 1996b, 2001b). BSC designers use a unique management process known as cascading to align performance measures with a business strategy (Kaplan \& Norton, 1996b). The cascading process is a systematic approach to aligning the strategic business objectives with the operational performance measures and actions.

In the literature on strategic performance measurement, firms are increasingly implementing new performance measurement systems to track non-financial metrics (Andrews, 1996; Banker et al., 2000; Frigo, 2002; Parry, Sharp, Wallace, \& Vreeland, 1994; Said, HassabElnaby, \& Wier, 2003). The current strategic management and managerial accounting literature on the balanced scorecard suggests the existence of strong links between strategic plans and performance measures (Kloot \& Martin, 2000). Kaplan and Norton (2001a) suggested that cause-and-effect relations exist among four perspectives in the BSC model. Most empirical studies have reported that such relations do exist (such as Banker et al., 2004; Ittner, Larcker, \& Randall, 2003; Kaplan \& Norton, 1992, 1993, 1996a, 1996b, 1996c, 2001a, 2001b, 2001c, 2001d, 2004a, 2004b, 2004c, 2004d; Lipe \& Salterio, 2002; Michael, 2003; Nørreklit, 2000). However, few studies have documented the linkages and drivers among the four strategic perspectives and measures of the BSC model (Bryant et al., 2004; Huang, Chu, \& Wang, 2007; Malina \& Selto, 2001; Yang \& Tung, 2006).

In order to examine the descriptive validity of the balanced scorecard as a causal model of leading and lagging indicators of non-financial and financial performance, Malina (2001) used the structural equation model (SEM) to empirically test the causal relations among the selected BSC measures of 31 North American distributors. Different from earlier management accounting studies that have investigated the BSC model by using data from a single organization or industry (Bryant et al., 2004; Malina \& Selto, 2001) utilized cross-sectional data involving seven archival measures from 125 firms over five years as a proxy for typical outcome measures of the four BSC perspectives. By using the SEM, Bryant et al. (2004) found that a model that allows each outcome measure to be associated with outcome measures in all higher-level BSC perspectives captures the value creation process more accurately than a relatively simple model in which each measure drives only the next perspective in the BSC hierarchy. Yang and Tung (2006) collected data from all 21 general hospitals in a public hospital system and their supervising agency during 2000-2002, and found that causal relationships among the performance indicators of the BSC framework exist in the hospitals industry. Similarly, by using path analysis Yang and Tung (2006) identified significant causal relationships among four perspectives in the BSC model.

Inspired by these studies, the second purpose of this paper is to fill in the research gap and to employ the same methodology (that is, the structural equation modeling) to investigate the causal rela- tions, linkages, drivers, and time-lag effects among different performance perspectives of the balanced scorecard concerning time-lag effects. Taiwanese high-tech firms during the period 2003-2005 were used as the research sample. In this work, strategic linkage is the process of linking strategic perspectives with corporate strategic objectives and performance measures. Owing to this strategic linkage process, the firm-level BSC integrated model comprises controllable, accounting-based financial and operations-based non-financial performance measures that are strategically aligned with corporate strategy.

\section{Methodology}

\subsection{Research framework}

The BSC model involves two main improvements over traditional performance measurement systems. First, the BSC model identifies four areas that are vital for competitiveness in almost all organizations. Second, the model makes explicit the links among leading and lagging measures of financial and non-financial performance (Malina, 2001). Recently, various works have investigated the causal relations linking non-financial perspectives and performance. Most scholars agree that a link does exist between non-financial perspectives and performance (e.g., Andrews, 1996; Banker et al., 2000; Frigo, 2002; Parry et al., 1994; Said et al., 2003). However, empirical studies that have examined the timelag effects are still limited (Wu \& Chen, 2006). To full in the research gap, this paper developed a dynamic integrated framework, and empirically studied the causal relations, alignments, linkages, drivers and effects that link the different perspectives of the research framework. By using Taiwanese high-tech firms as the research sample, this work examined the strategic linkage process and analyzed the relationships among non-financial perspectives (that is, the learning-growth and internal process perspectives) and organizational performance.

Fig. 1 illustrates the research framework. The conceptual model in Fig. 1 comprises a framework of non-financial perspectives (including learning-growth, internal process and customer perspective) and financial performance. The current balanced scorecard literature suggests that linkages should exist between non-financial performance perspectives and financial performance measures. The proposed model assumes a four-construct system containing two causal paths feeding into the outcome construct. Restated, positive relationships exist between the learning-growth perspective and the internal process perspective (H1a), financial perspective (H1b), and customer perspective (H1c). The internal process perspective mediates the relationship between learning-growth perspective and both the financial perspective (H2a), and customer perspective (H2b). The BSC model is adopted as a theoretical basis to explain how the relationship coordinates strategic linkage and strategic perspective to achieve sustained competitive advantage and organizational performance. The structural equation model (SEM) was used to study the causal effects and model fit. The indicators of the measurement perspectives were determined to facilitate the subsequent statistical analysis.

Fig. 1 illustrates the conceptual model used to examine the influence of a high-tech firm's learning-growth on its internal process management during the coming year, and on its customer and financial performance during the following year. This study differentiated financial and customer perspective measures over a 2-year time period, and internal process activities over a regular 1-year time period. The time periods are divided into three different levels depending upon the strategic linkage process and value drivers, namely: $t$ (that is, learning-growth perspective), $t+1$ (that is, internal process perspective), and $t+2$ (that is, customer and financial 


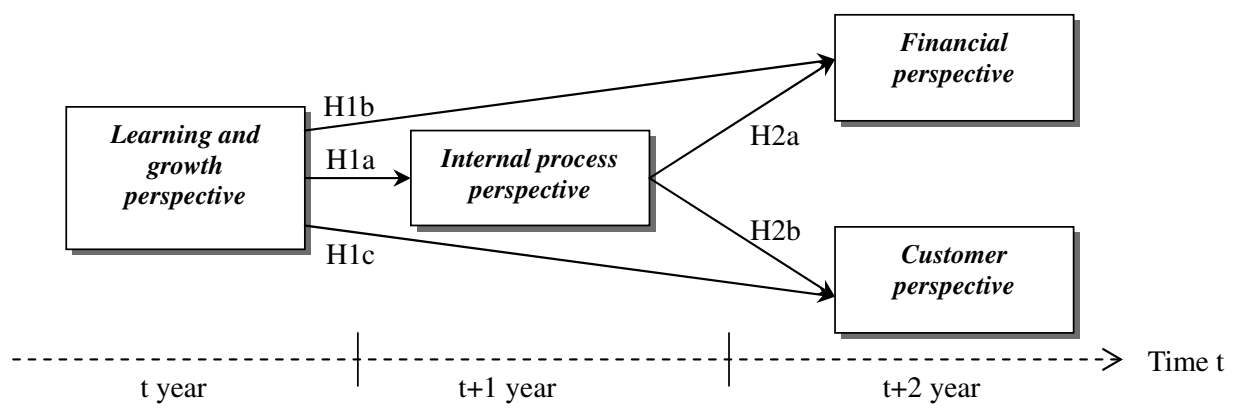

Fig. 1. Research framework: A dynamic BSC integrated model.

perspective), as illustrated in Fig. 1. One reason that a dynamic integrated model was designed and used is that organizational learning-growth and internal process may not immediately influence customer or financial performance and can take several years to deliver the results. Consequently, to enhance our ability to make causal inferences regarding influences on organizational performance, the lagged structure was designed in this work.

\subsection{Measurement of variables}

According to Kaplan and Norton (1992), the BSC measures can be either qualitative or quantitative, and can provide either outcome (or lagging indicators) or performance drivers (or leading indicators). Although the BSC model should ideally be tailored to the unique strategies of individual firms, evidence demonstrates that firms tend to rely on generic measures, especially as measures of perspective outcomes (Bryant et al., 2004). Therefore, regarding the operationalization and measures of the four BSC perspectives, this paper incorporated measurements that have been widely used in the existing literature. The measurement of variables used in this work resembles that of previous studies (Chu, Lin, Hsiung, \& Liu, 2006; Kaplan \& Norton, 2004b; Lin, Chen, \& Wu, 2006; Lin \& Chen, 2005; Lin, Lee, \& Hung, 2006; Lin, Li, \& Chen, 2006; Wang \& Chang, 2005).

Kaplan and Norton (1996b) stated that all balanced scorecards include certain generic measures. These generic measures tend to be core outcome measures, which reflect the common goals of numerous strategies, and similar structures across industries and companies. Accordingly, in this work the learning-growth perspective is the exogenous or independent variable in the SEM analysis. The learning-growth perspective is measured by using R\&D density (RDD) and R\&D productivity (RDP). Meanwhile, the endogenous or dependent variables are the internal process, customer, and financial perspective. The internal process perspective is measured based on the productivity per employee (PPE) and administrative expense per employee (AEPE). Furthermore, the customer perspective is measured based on the sales growth rate (GR) and product acceptance rate (AR). Financial perspective is measured using return on assets (ROA) and return on stockholders equity (ROE). Natural logarithmic transformation was applied to the RDP, PPE, and AEPE, to considerably reduce the distribution skewness. The SEM model was statistically analyzed following the logarithmic transformations. The measures used in this work are summarized below.

Learning-growth perspective. The two variables were reported on an annual basis for the year 2003. Those ratios measuring the R\&D capability are defined as follows

$\mathrm{R} \& \mathrm{D}$ density (RDD) : R\&D density

$=(\mathrm{R} \& \mathrm{D}$ expenses $/$ net sales $)$

$R \& D$ productivity (RDP) : Income per R\&D expenses

$=($ Net income after tax $/ R \& D$ expenses $)$
Internal process perspective. The two variables were reported on an annual basis for the year 2004. Those ratios measuring the efficiency of operations management and administrative process are defined as follows

Productivity per employee (PPE)

$=($ Net sales / total number of employee $)$

Administrative expenses per employee (AEPE)

$=($ Administrative expense/total number of employee $)$

Customer perspective. Two variables were reported on an annual basis for the year 2005. Growth rate (GR) measures the sales growth rate, while acceptance rate measures the product acceptance rate. The two measures are defined as follows

\section{Growth rate (GR)}

$=($ Net sales this year-net sales last year $) /$ net sales last year Acceptance rate (AR)

$=1-($ sales returns and allowances/net sales $)$

Financial perspective. Two measures were employed. The key measure of financial performance is its profitability, which captures a firm's return on its investments. Additionally, research on firm profitability has traditionally relied on accounting values such as return on assets (ROA) (Andersen \& Segars, 2001; Choe, 2003; Li \& Ye, 1999; Rumelt, 1991; Schmalensee, 1985), and return on stockholder equity (ROE) (Byrd \& Davidson, 2003; Cho \& Pucik, 2005; Delios \& Beamish, 1999). Traditionally, firm performance can be measured in accounting terms by return on assets (ROA) and return on stockholder equity (ROE) in the firm. These two measures were thus employed in this research. The variable was reported on an annual basis for the year 2005 .

Return on assets (ROA)

$=($ Net income after tax/average total assets $)$

Return on stockholders equity (ROE)

$=$ (Operating income/average common stockholder equity)

\subsection{Strategic linkage process in the dynamic BSC integrated model}

The key model components, strategic objectives and performance measures within each BSC perspective employed in this paper are summarized in Table 1. Measurement is fundamental and essential to the BSC frame. A key issue is the selection or design of the most appropriate and helpful measures. The BSC framework requires systematically linking the strategy to the value proposition, then to specific objectives, and then to measures for those objectives (Kaplan \& Norton, 1996b, 2001b). Eight generic outcome measures were thus used. These measures proxy for outcomes of 
Table 1

Strategic linkages, strategic objectives and performance measures for high-tech firms

\begin{tabular}{|c|c|c|c|c|}
\hline BSC perspective & Strategic objectives & Performance measures & Leading/lagging measurements & Effect of time delays \\
\hline $\begin{array}{c}\text { Financial } \\
\text { perspective } \\
\text { Customer } \\
\text { perspective }\end{array}$ & $\begin{array}{l}\text { Sustainable shareholder value } \\
\text { Asset utilization } \\
\text { Customer satisfaction } \\
\text { Customer growth } \\
\text { Product acceptance } \\
\text { Efficient administration } \\
\text { Efficient operations management } \\
\text { R\&D capability } \\
\text { R\&D density }\end{array}$ & $\begin{array}{l}\text { ROA } \\
\text { ROE } \\
\text { Growth rate (\%) } \\
\text { Acceptance rate (\%) } \\
\text { Productivity per employee } \\
\text { Administrative expense per employee } \\
\text { R\&D density } \\
\text { R\&D productivity }\end{array}$ & $\begin{array}{l}\text { Lagging measurement } \\
\text { Lagging measurement } \\
\text { Leading measurement } \\
\text { Leading measurement }\end{array}$ & $\begin{array}{l}\text { 2-year } \\
\text { 2-year } \\
\text { 1-year } \\
\text { - }\end{array}$ \\
\hline
\end{tabular}

BSC perspective, including: R\&D density, R\&D productivity, productivity per employee, administrative expenses per employee, growth rate (\%), acceptance rate (\%), ROA, and ROE.

All measures in four strategic perspectives, frequently called as key performance indicators (KPIs), must be linked together in a cause-and-effect relationship. The strategic objectives involved in the financial perspective stress the importance of ensuring sustainable shareholder value and maximizing asset utilization. The customer perspective identifies how high-tech firms must meet customer expectations regarding satisfaction, quality, and product acceptance to realize their customer satisfaction, growth, and acceptance objectives. The internal process perspective focuses on creating efficient administrative processes and operations management. Moreover, the learning-growth perspective supports the creation of R\&D capability and R\&D density. The assumption of a time-lag effect is essential because it permits management to use the performance measures in nonfinancial performance to forecast future financial performance. Previous studies found that effective management control using the BSC indirectly lead to positive outcomes via strategic alignment (Malina \& Selto, 2001).

\subsection{Data collection and sample}

This work used a firm-level analysis that adopted a longitudinal design and secondary data to explore causal relationships and the time-lag effects among performance indicators and strategic linkages in the BSC model. Data were obtained from the Taiwan financial database maintained by the Taiwan Economic Journal (TEJ) for fiscal years 2003, 2004, and 2005. The TEJ financial database is the most comprehensive and widely used database in Taiwan; it provides a highly representative picture of various financial rates and information regarding listed companies in Taiwan Stock Exchange Corporation (TSEC). To ensure sample homogeneity, only those high-tech firms that are listed on the Taiwan public stock exchange market were used in this work, including integrated circuits, electro-optical, semiconductor, computers and peripherals, and automation firms. The following criteria were used in sample selection: (1) high-tech and electronic information firms; (2) publicly listed firms; (3) with three-year financial data available to provide stable measures. The authors screened candidates by accessing the TEJ database and reviewing related financial reports or prospectus. After deleting firms with missing values and/or outliers, the final sample comprised 240 firms, with a total of 720 observations, thus providing a sufficiently large sample for the subsequent statistical analysis.

\subsection{Analytical models}

The LISREL statistical package was used to test the research model illustrated in Fig. 1. Descriptive statistics and Pearson correlations were first calculated, and then the structural equation model (SEM) was analyzed. Introduced by Jöreskog in 1973, the structural equation model comprises two parts, the measurement model and the structural equation model. The measurement model indicates how latent variables or hypothetical constructs depend upon or are indicated by the observed variables. The model describes the measurement properties (reliabilities and validities) of the observed variables. Meanwhile, the structural equation model specifies the causal relationships among the latent variables, describes the causal effects, and assigns the explained and unexplained variance (Jöreskog \& Sörbom, 1996a, 1996b).

The model is specifically designed to deal with models that incorporate latent variables, measurement errors and reciprocal causation. Moreover, the LISREL model is designed to estimate and test Structural Equation Models (SEMs). LISREL analysis is designed to develop and confirm a model comprising specified causal relations. SEMs are statistical models of the linear relationships among latent (unobserved) variables and manifest (observed) variables. One of the unique characteristics of SEM is its ability to provide parameter estimates for relationships among unobserved variables. Structural Equation Modeling resembles path analysis in providing parameter estimates of the direct and indirect links between observed variables (Jöreskog \& Sörbom, 1996a, 1996b). Fig. 2 illustrates the hypothetical model used in this work. This work selects the model components and the structural relationships among them based on the above propositions. The hypothesized model incorporates four constructs, eight observable indicators, measurement and latent variable errors, and the intercorrelations among them.

\section{Empirical results}

\subsection{Descriptive statistics and correlation analysis}

Table 2 summarizes the descriptive statistics and the Pearson correlation coefficients for variables in this work. The correlation analysis highlights the relationships among the independent, 


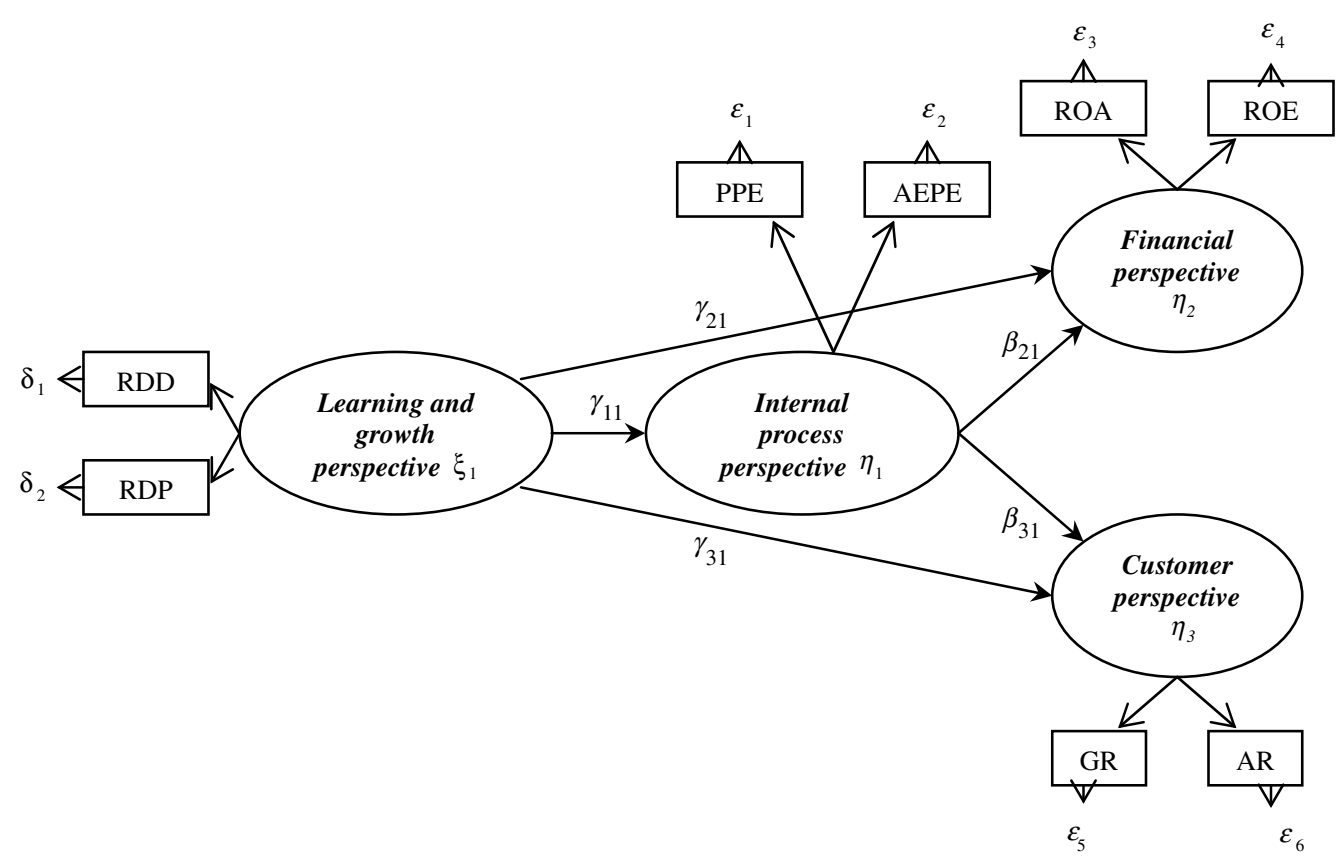

Fig. 2. Strategic linkage process and value drivers: A causal model.

mediating and dependent variables in this work. All variables were further examined for possible multicollinearity by using variance inflation and tolerance statistics, and no multicollinearity was detected.

\subsection{SEM analysis}

This work used the maximum likelihood (ML) estimation (Jöreskog \& Sörbom, 1996a, 1996b) to examine the structural equation model. The full model comprises the structural model, which included four latent variables and eight manifest variables, and the measurement model, which specified the relationships between the latent and manifest variables (as illustrated in Fig. 2). The hypothesized model illustrated in Fig. 3 presents the results of the relationships between the exogenous and endogenous variables and the relationships between the endogenous variables. The model illustrates the hypothesized relationships among the learning-growth, internal process, customer, and financial perspectives. The 240 electronic information firms were used to test the hypothesized relationships.

\subsubsection{Model test}

Table 3 summarizes the results of the model comparison, including the hypothesized model and the two alternative models (namely models 1 and 2). Compared to the hypothesized model, model 1 decreases the path from the learning-growth to the financial perspective. Moreover, model 2 decreases the path from the learning-growth to the customer perspective. The hypothesized model provided a better fit than the model 1 or model 2 did. The hypothesized model had a significant chi-squire statistic $\left(\chi^{2}=41.88\right.$ with $\left.d f=15\right)$, indicating acceptable model fit. Common criteria for testing an overall model are as follows: (1) A ratio of model-fit statistics based on a degree of freedom not exceeding 3; and (2) Goodness of fit indices, particularly (a) goodness of fit index (GFI), (b) adjusted goodness-of-fit index (AGFI), (c) normed fit index (NFI), (d) comparative fit index (CFI), each of which must exceed a threshold value of 0.9 for a model to be classified as closely fitting the model (Bagozzi \& Yi, 1988). For this model, the GFI, AGFI and CFI exceed the cut-off value of 0.90 , and are all higher than those of models 1 and 2. The expected cross-validation index (ECVI) used to compare alternative models also suggests that the hypothesized model provides the most suitable description of the data, because it has the lowest value. The ECVI was clearly within the 90\% confidence interval (0.286-0.448), demonstrating that the hypothesized model has statistically significant model fit, thus was the best fitting model.

Table 2

Descriptive statistics and Pearson correlation analysis $(N=240)$

\begin{tabular}{|c|c|c|c|c|c|c|c|c|c|c|}
\hline & Mean & SD & $(1)$ & $(2)$ & (3) & $(4)$ & (5) & (6) & $(7)$ & $(8)$ \\
\hline R\&D density & 0.050 & 0.053 & $1.000_{*:}$ & & & & & & & \\
\hline R\&D productivity & 2.788 & 0.037 & $0.280_{* * * *}^{* * *}$ & 1.000 & & & & & & \\
\hline Productivity per employee & 3.968 & 0.340 & $0.258^{* *}$ & $0.090_{* *}$ & $1.000_{* *}$ & & & & & \\
\hline Administrative expense per employee & 2.375 & 0.385 & 0.153 & $0.230_{* * *}^{* *}$ & $0.244_{* *}^{* *}$ & $1.000_{* *}$ & & & & \\
\hline Return on assets & 0.086 & 0.118 & 0.191 & $0.393_{* * *}$ & $0.201^{*}$ & $0.299_{* * *}$ & $1.000_{* *}$ & & & \\
\hline Return on stockholders' equity & 0.062 & 0.267 & 0.136 & $0.370_{* * * *}^{* * *}$ & 0.169 & $0.409^{* * *}$ & $0.222^{* *}$ & 1.000 & & \\
\hline Growth rate & 0.574 & 0.360 & 0.113 & $0.230_{* * *}^{* *}$ & 0.112 & 0.191 & $0.142_{* *}$ & $0.053_{* * *}$ & 1.000 & \\
\hline Acceptance rate & 0.984 & 0.020 & 0.214 & $0.223^{*-4}$ & 0.154 & 0.007 & $0.251^{* *}$ & $0.277^{* * * *}$ & 0.018 & 1.000 \\
\hline
\end{tabular}

Note: ${ }^{*} p<0.1,{ }^{* *} \quad p<0.05$ and ${ }^{* * *} p<0.01$.

Mean and standard deviation provided for transformed variable. 


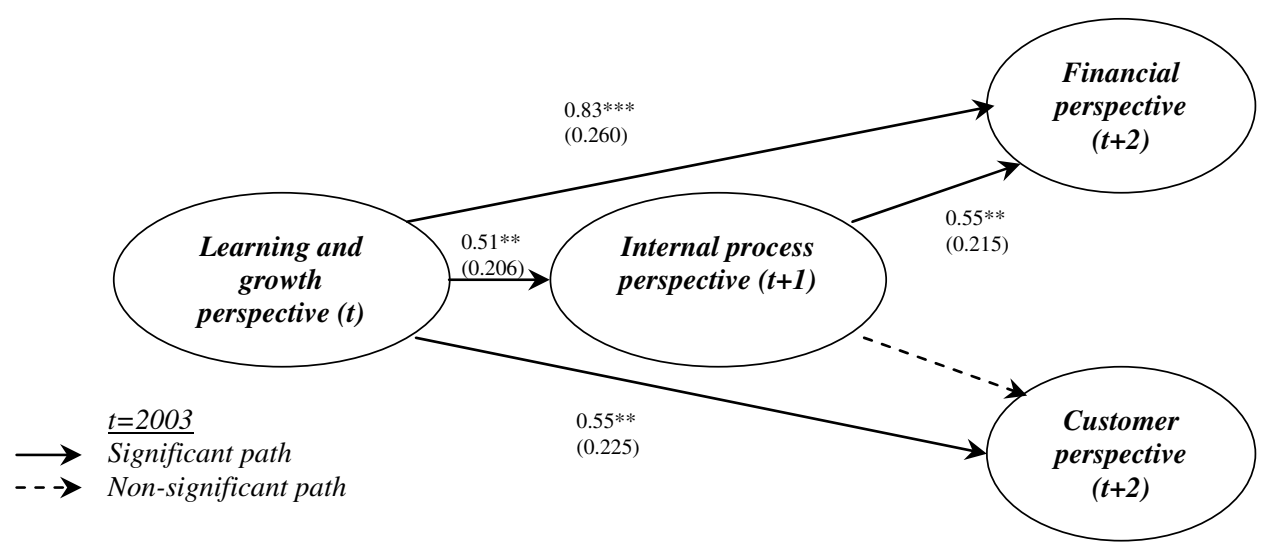

Fig. 3. Strategic linkage process and value drivers: A causal model involving computed parameters.

Table 3

Results of model comparison $(N=240)$

\begin{tabular}{|c|c|c|c|c|c|c|c|c|c|c|c|}
\hline Model & $\chi^{2}$ & $D f$ & $\left(\chi^{2} / \mathrm{d} f\right)$ & $\Delta \chi^{2}$ & $\Delta \mathrm{d} f$ & GFI & AGFI & NFI & CFI & RMSEA & ECVI \\
\hline Hypothesized Model & 41.88 & 15 & 2.79 & - & - & 0.96 & 0.90 & 0.87 & 0.91 & 0.086 & 0.351 \\
\hline Model $1^{\mathrm{a}}$ & 45.82 & 16 & 2.86 & 3.94 & 1 & 0.95 & 0.89 & 0.86 & 0.89 & 0.089 & 0.359 \\
\hline Model $2^{\mathrm{b}}$ & 51.08 & 17 & 3.00 & 9.20 & 2 & 0.95 & 0.89 & 0.84 & 0.88 & 0.092 & 0.373 \\
\hline
\end{tabular}

${ }^{a}$ In comparison to hypothesized Model, the model 1decreases the path from IPP to FP.

b Model 2 decreases the path from IPP to CP.

\subsubsection{Goodness-of-fit test}

Table 3 summarized the statistics for the goodness-of-fit test. The results of testing the hypothesized model revealed good fit. A ratio of model-fit statistics based on degree of freedom below 3 indicates adequate model fit $\left(\chi^{2} / d f=2.79\right)$. RMSEA value reached an acceptable value of 0.08 (with a $90 \%$ confidence interval $[0.0561 ; 0.118])$. Specifically, the GFI, AGFI and CFI values reached an acceptable value of $0.9(0.96,0.90$ and 0.91 , respectively), while the NFI value approached an acceptable value of 0.9 . The hypothesized model in Fig. 3 thus can be classified as closely fitting the data. Table 3 lists the results of the goodness-of fit measures of the hypothesized model. The other indicators also suggest that the hypothesized model has acceptable performance, including incremental fit index (IFI), root mean square residual (RMR) and standardized RMR (SRMR) of $0.91,0.0038$ and 0.05 , respectively.

\subsubsection{Hypothesis test}

To test Hypotheses 1a through 2c, the proposed theoretical model was tested using the LISREL 8.52 version. The following paths were estimated: path between learning-growth and internal process perspectives (H1a), path between learning-growth and financial perspectives (H1b), path between learning-growth and customer perspectives (H1c), between internal process and financial perspectives ( $\mathrm{H} 2 \mathrm{a}$ ) and between internal process and customer perspectives $(\mathrm{H} 2 \mathrm{~b})$. The hypotheses regarding the relationships were tested based on the associated t-statistics. $t$-values exceeding 1.65 or 1.98 or 2.576 were considered significant at the $0.10,0.05$ and 0.01 levels, respectively. Learning-growth significantly and positively influenced the internal process perspective $\left(\gamma_{11}=0.51\right.$, $t$-value $=2.48$ ). Furthermore, learning-growth significantly and positively influenced $(P<0.05)$ both the financial perspective $\left(\gamma_{21}=0.83, t\right.$-value $\left.=3.19\right)$ and the customer perspective $\left(\gamma_{31}=\right.$ $0.55, t$-value $=2.44$ ). Thus, Hypotheses $1 \mathrm{a}, 1 \mathrm{~b}$ and $1 \mathrm{c}$ were supported. In support of Hypothesis 2a, the internal process was positively associated with financial perspective $\left(\beta_{21}=0.55, t\right.$-value $=$ $2.56, P<0.05)$. Consequently, Hypothesis 2 a was supported. However, contradicting the predictions, no significant association was identified between the internal process and the customer perspec-
Table 4

Parameter estimates for structural equations model

\begin{tabular}{|c|c|c|c|}
\hline Hypothesized model & $\begin{array}{l}\text { Parameter } \\
\text { estimates }\end{array}$ & $\begin{array}{l}\text { Standard } \\
\text { error }\end{array}$ & $\begin{array}{l}t- \\
\text { value }\end{array}$ \\
\hline \multicolumn{4}{|l|}{ Path } \\
\hline $\begin{array}{l}\text { H1a: Learning and growth } \\
\text { perspective } \rightarrow \text { Internal process perspective } \\
\left(\gamma_{11}\right)\end{array}$ & 0.51 & 0.206 & 2.48 \\
\hline $\begin{array}{l}\text { H1b: Learning and growth } \\
\text { perspective } \rightarrow \text { Financial perspective }\left(\gamma_{21}\right)\end{array}$ & $0.83^{* * *}$ & 0.260 & 3.19 \\
\hline $\begin{array}{l}\text { H1c: Learning and growth } \\
\text { perspective } \rightarrow \text { Customer perspective }\left(\gamma_{31}\right)\end{array}$ & $0.55^{* *}$ & 0.225 & 2.44 \\
\hline $\begin{array}{l}\text { H2a: Internal process perspective } \rightarrow \text { Financial } \\
\text { perspective }\left(\beta_{21}\right)\end{array}$ & $0.55^{* *}$ & 0.215 & 2.56 \\
\hline $\begin{array}{l}\text { H2b: Internal process perspective } \rightarrow \text { Customer } \\
\text { perspective }\left(\beta_{31}\right)\end{array}$ & -0.30 & -0.682 & -0.44 \\
\hline
\end{tabular}

tives (H2c). Table 4 lists the results of the parameter estimates of the hypothesized model. Four hypothesized relationships were classified as significant.

\subsection{Discussion: direct effect and indirect effect}

Table 5 lists the direct and indirect effects of the hypothesized model. According to Table 5, each of these relations exhibits a significant time-lag effect. Effective customer management processes require strong, enabling support from information technology, employee competencies, and culture and climate (Kaplan \& Norton, 2004b). The outcomes as determined based on the successful

\section{Table 5}

Direct effect and indirect effect

\begin{tabular}{llll}
\hline & $\begin{array}{l}\text { Internal process } \\
\text { perspective }\end{array}$ & $\begin{array}{l}\text { Customer } \\
\text { perspective }\end{array}$ & $\begin{array}{l}\text { Financial } \\
\text { perspective }\end{array}$ \\
\hline $\begin{array}{l}\text { Learning and growth } \\
\text { perspective }\end{array}$ & & & \\
$\begin{array}{l}\text { Direct Effect } \\
\text { Indirect Effect }\end{array}$ & 0.51 & 0.55 & 0.83 \\
Total Effect & 0.51 & - & 0.2805 \\
\hline
\end{tabular}


customer perspective appear mainly in sales growth and acceptance rate. This work identifies a direct and positive driver effect between the learning-growth and customer perspectives (direct effect $=0.55, p<0.01$ ). Kaplan and Norton established the learning and growth perspective as strategically important in the BSC model and observed that the learning-growth perspective is the foundation of all strategy. Restated, learning and growth, the most fundamental elements of the balanced scorecard, may influence internal process, in turn influencing the financial perspective (total effect $=1.11, p<0.01$ ).

The right accomplishments in this arena or perspective enable performance improvement and achievement of objectives or themes in the other three perspectives (namely the internal process, customer, and financial perspectives). Notably, the fourth perspective of the BSC model, learning and growth, describes organization intangible assets and their role in strategy (Kaplan \&

Norton, 2004c). In this work, the learning and growth perspectives covered two key issues involving high-tech firms: developing R\&D capability, and increasing R\&D density. Consequently, sustaining competitive advantage requires high-tech firms to pursue continuous $R \& D$ to create new products, services, processes and financial performance. Successful R\&D capability (that is learning-growth perspective) directly drives customer growth, customer satisfaction, and product acceptance. Demonstrating the effects of the time-lag between the effect of learning-growth and both customer and financial performance in high-tech industry is the objective of this work. However, R\&D capability or density may not have an immediate impact, often taking two years to show results; these lags may have duration of two years.

The SEM results clearly indicate the mediating role of internal process in the influence of learning-growth on financial perspective. The internal process mediates the relationship between learning and growth and financial perspectives. The internal process is directly connected to the financial perspective. Drawing downwards links from internal process to the learning-growth perspective, firms can identify the R\&D capability, competency, and productivity that foster excellent internal process management. One observation indicates that learning-growth exerts a lag effect on internal process, namely that the effect occurs during the second year. Another observation also indicates that internal process exerts a lag effect on financial perspective, namely that the effect occurs in the second year. Strategic linkages are separated by a one year delay. Consequently, financial value is created through learning-growth and internal process. The financial perspective describes the outcomes, that is, what the firm hopes to achieve. The financial perspective dealt with in this study comprised two main issues: ensuring sustainable shareholder value, and maximizing asset utilization for high-tech firms. Processes in the learning-growth and internal process perspectives drive the implementation of strategy. Effective and aligned internal processes determine how value is created and sustained (Kaplan \& Norton, 2004d). Like previous studies (Kaplan \& Norton, 1993, 1996a, 1996b, 1996c, 2001a, 2001b, 2001c, 2001d, 2004a, 2004b, 2004c, 2004d), current balanced scorecard literature suggests that a link should exist between non-financial performance perspectives and financial performance measures, as well as between lagging and leading measurements. This work also provides empirical supports to these previous claims.

\section{Conclusions and future research}

\subsection{Conclusions}

This work examined four research questions: (a) how do the learning/growth and internal/business processes drive customer and financial perspectives in the high-tech industry? (b) What are the relationships between lagging and leading measurements? (c) Do time-lag effects influence value creation and improve organizational performance (that is, customer and financial performance)? (d) How can a high-tech firm translate its learning/growth perspective into increased financial performance, whether in terms of productivity, sales growth, product acceptance rate or other indicators of organizational performance?

This work used an analytical tool to address these questions, namely the SEM model. This work referred to the BSC literature to identify a set of variables that reflected perspectives and performance. This study examines whether the causal relationships among the strategic perspectives and performance indicators of the balanced scorecard framework exist in high-tech firms. This work empirically tests the descriptive validity of the balanced scorecard as a causal model of leading and lagging measurements of non-financial and financial performance in relation to time-lag effects. A dynamic integrated model was established to investigate the impact of the balanced scorecard on the Taiwanese high-tech industry, and to examine the relationships among different perspectives of the balanced scorecard.

The main findings of this work are summarized as follows. This work developed five hypotheses that identified the important objectives and strategic linkages among different perspectives of the balanced scorecard. The analytical results strongly supported four of the hypotheses. Moreover, the results of the SEM analysis identified significant causal relationships among four perspectives in the dynamic integrated model. Notably, the results demonstrated the existence of a direct positive driver effect between the learning-growth and both the customer and financial perspectives, as well as that the internal process (leading measurements) mediated the relationship between learning-growth (leading measurements) and financial perspective (lagging measurements). The analytical results indicated that time tag positively influenced the non-financial and financial perspectives, and that these perspectives were markedly correlated with strategic linkages. Successful implementation of BSC requires an optimal understanding of the strategic links among the non-financial and financial perspectives. This work designed an empirical model for exploring the relationships among contextual constructs, including the learning-growth, internal process, customer and financial perspectives.

\subsection{Implications, limitations, and future research}

Several practical implications can be drawn from this investigation. The BSC is a powerful approach to strategic management and organizational change for high-tech firms in Taiwan. Management thus should spend time and energy on learning how to practically apply the integrated BSC model to achieve organizational competitive advantages. This work concludes that administrators of hightech firms can use this analysis to help them identify and manage strategic indicators and linkages regarding time-lag effects when adopting the BSC model.

This investigation also has some limitations, which should be noted to benefit further work in the same area. These limitations may create an opportunity for future research on the balanced scorecard view and value creation in other industries. First, a particular data set was used, and future studies should examine other data sets to enhance the model validity. Second, the empirical model proposed in this investigation is a preliminary method that requires further examinations. Therefore, the findings and implications should be generalized in so far as future groups of programs resemble the sample. Despite its limitations, this work is expected to provide a basis for further research on strategic 
linkage process and value creation in the high-tech industry in other emerging economies.

The approach presented in this work can be replicated in other nations, industries and companies. Therefore, future studies can focus on validating the proposed BSC model and associated strategic objectives and performance measures, as well as on implementing BSC to the other industries or companies to test the effectiveness of this approach.

\section{References}

Andersen, T. J., \& Segars, A. H. (2001). The impact of IT on decision structure and firm performance: Evidence from the textile and apparel industry. Information E Management, 39(2), 85-100.

Andrews, K. Z. (1996). Two kinds of performance measures. Harvard Business Review, 74(1), 8-9.

Bagozzi, R. P., \& Yi, Y. (1988). On the evaluation of structural equation models. Journal of the Academy of Marketing Science, 16(1), 74-94.

Banker, R. D., Chang, H., \& Pizzini, M. J. (2004). The balanced scorecard: Judgmental effects of performance measures linked to strategy. Accounting Review, 79(1), $1-23$.

Banker, R. D., Potter, G., \& Srinivasan, D. (2000). An empirical investigation of an incentive plan that includes nonfinancial performance measures. Accounting Review, 75(1), 65-92.

Blundell, B., Sayers, H., \& Shanahan, Y. (2003). The adoption and use of the balanced scorecard in New Zealand: A survey of the top 40 companies. Pacific Accounting Review, 15(1), 49-74.

Bryant, L., Jones, D. A., \& Widener, S. K. (2004). Managing value creation within the firm: An examination of multiple performance measures. Journal of Management Accounting Research, 16, 107-133.

Byrd, T. A., \& Davidson, N. W. (2003). Examining possible antecedents of IT impact on the supply chain and its effect on firm performance. Information $\mathcal{E}$ Management, 41(2), 243-255.

Chen, C. J., \& Huang, C. C. (2004). A multiple criteria evaluation of high-tech industries for the science-based industrial park in Taiwan. Information $\mathcal{E}$ Management, 41(7), 839-851.

Chen, C. J., Wu, H. L., \& Lin, B. W. (2006). Evaluating the development of high-tech industries: Taiwan's science park. Technological Forecasting and Social Change, $73(4), 452-465$.

Choe, J. M. (2003). The effect of environmental uncertainty and strategic applications of IS on a firm's performance. Information $\mathcal{E}$ Management, 40(4), 257-268.

Cho, H. J., \& Pucik, V. (2005). Relationship between innovativeness, quality, growth, profitability, and market value. Strategic Management Journal, 26(6), $555-575$.

Chu, P. Y., Lin, Y. L., Hsiung, H. H., \& Liu, T. Y. (2006). Intellectual capital: An empirical study of ITRI. Technological Forecasting and Social Change, 73(7), 886-902.

Delios, A., \& Beamish, P. W. (1999). Ownership strategy of Japanese firms: Transactional, institutional, and experience influences. Strategic Management Journal, 20(10), 915-933.

Duh, R. R., Chow, C. W., \& Chen, H. (2006). Strategy, IT applications for planning and control, and firm performance: The impact of impediments to IT implementation. Information \& Management, 43(8), 939-949.

Fernandes, K. J., Raja, V., \& Whalleyc, A. (2006). Lessons from implementing the balanced scorecard in a small and medium size manufacturing organization. Technovation, 26(5-6), 623-634.

Frigo, M. L. (2002). Nonfinancial performance measures and strategy execution Strategic Finance, 84(2), 6-8.

Hoque, Z., \& James, W. (2000). Linking balanced scorecard measures to size and market factors: Impact on organizational performance. Journal of Management Accounting Research, 12, 1-16.

Huang, H. C., Chu, W., \& Wang, W. K. (2007). Strategic performance measurement and value drivers: Evidence from the international tourist hotels in an emerging economy. Service Industries Journal, 27(8), 1111-1128.

Huang, S. M., Lee, C. L., \& Kao, A. C. (2006). Balancing performance measures for information security management - A balanced scorecard framework. Industria Management \& Data Systems, 106(1-2), 242-255.

Hu, M. W., \& Schive, C. (1998). The changing competitiveness of Taiwan's manufacturing SMEs. Small Business Economics, 11(4), 315-326.

Ittner, C. D., Larcker, D. F., \& Randall, T. (2003). Performance implications of strategic performance measurement in financial services firms. Accounting Organizations and Society, 28(7-8), 715-741.

Jöreskog, K., \& Sörbom, D. (1996a). PRELIS 2 user's reference guide. Chicago: Scientific Software International.

Jöreskog, K., \& Sörbom, D. (1996b). LISREL 8: Structural equation modeling with the SIMPLIS command language. Chicago: Scientific Software International.

Kaplan, R. S., \& Norton, D. P. (1992). The balance scorecard-measures that drive performance. Harvard Business Review, 70(1), 71-79.

Kaplan, R. S., \& Norton, D. P. (1993). Putting the balanced scorecard to work. Harvard Business Review, 71(5), 134-140.
Kaplan, R. S., \& Norton, D. P. (1996a). Using the balance scorecard as a strategic management system. Harvard Business Review, 74(1), 75-85.

Kaplan, R. S., \& Norton, D. P. (1996b). The balanced scorecard. Boston, NA: Harvard Business School Press.

Kaplan, R. S., \& Norton, D. P. (1996c). Linking the balanced scorecard to strategy. California Management Review, 39(1), 53-79.

Kaplan, R. S., \& Norton, D. P. (2001a). The strategy-focused organization. Boston, MA: Harvard Business School Press.

Kaplan, R. S., \& Norton, D. P. (2001b). Transforming the balanced scorecard from performance measurement to strategic management: Part I. Accounting Horizons, 15(1), 87-106.

Kaplan, R. S., \& Norton, D. P. (2001c). The strategy-focused organization. Strategy \& Leadership, 29(3), 41-43.

Kaplan, R. S., \& Norton, D. P. (2001d). Transforming the balanced scorecard from performance measurement to strategic management: Part II. Accounting Horizons, 15(2), 147-162.

Kaplan, R. S., \& Norton, D. P. (2004a). Strategy maps: Converting intangible assets into tangible outcomes. Boston, MA: Harvard Business School Press.

Kaplan, R. S., \& Norton, D. P. (2004b). Measuring the strategic readiness of intangible assets. Harvard Business Review, 82(2), 52-63.

Kaplan, R. S., \& Norton, D. P. (2004c). The strategy map: Guide to aligning intangible assets. Strategy $\mathcal{E}$ Leadership, 32(5), 10-17.

Kaplan, R. S., \& Norton, D. P. (2004d). How strategy maps frame an organization's objectives. Financial Executive, 20(2), 40-45.

Kaplan, R. S., \& Norton, D. P. (2006). Alignment: Using the balanced scorecard to create corporate synergies. Boston, NA: Harvard Business School Press.

Kloot, L., \& Martin, J. (2000). Strategic performance management: A balanced approach to performance management issues in local government. Management Accounting Research, 11(2), 231-251.

Knotts, T. L., Jones, S. C., \& Udell, G. G. (2006). Using a balanced approach to measure merchandising supplier performance. Measuring Business Excellence, 10(1), 4-13.

Lee, A. H. I., Chen, W. C. \& Chang, C. J. (2008). A fuzzy AHP and BSC approach for evaluating performance of IT department in the manufacturing industry in Taiwan. Expert Systems with Applications, 34(1), 96-107.

Lin, B. W., \& Chen, J. S. (2005). Corporate technology portfolios and R\&D performance measures: A study of technology intensive firms. $R E D$ Management, 35(2), 157-170.

Lin, B. W., Chen, C. J., \& Wu, H. L. (2006). Patent portfolio synergy, technology strategy, and firm performance. IEEE Transactions on Engineering Management, 53(1), 17-26.

Lin, B. W., Lee, Y., \& Hung, S. C. (2006). The effects of R\&D intensity and commercialization orientation on financial performance. Journal of Business Research, 59(6), 653-792.

Lin, B. W., Li, P. C., \& Chen, J. S. (2006). Social capital, capabilities, and entrepreneurial strategies: A study of Taiwanese high-tech new ventures. Technological Forecasting and Social Change, 73(2), 168-181.

Lipe, M. G., \& Salterio, S. (2002). A note on the judgmental effects of the balanced scorecard's information organization. Accounting, Organizations and Society, 27(6), 531-540.

Li, M., \& Ye, L. R. (1999). Information technology and firm performance: Linking with environmental, strategic and managerial contexts. Information $\mathcal{E}$ Management, 35(1), 43-51.

Malina, M.A. (2001). Management control and the balanced scorecard: An empirical test of causal relations. Dissertation of University of Colorado.

Malina, M. A., \& Selto, F. H. (2001). Communicating and controlling strategy: An empirical study of the effectiveness of the balanced scorecard. Journal of Management Accounting Research, 13, 47-90.

Maltz, A. C., Shenhar, A. J., \& Reilly, R. R. (2003). Beyond the balanced scorecard: Refining the search for organizational success measures. Long Range Planning, 36(2), 187-204.

Michael, R. (2003). The use of balanced scorecards in the strategic management of corporate communication. Corporate Communications: An International Journal, $8(1), 44-59$

Nørreklit, H. (2000). The balance on the balanced scorecard - A critical analysis of some of its assumptions. Management Accounting Research, 11(1), 65-88.

Parry, R. W., Jr., Sharp, F., Wallace, W. A., \& Vreeland, J. (1994). The role of service efforts and accomplishments reporting in total quality management. Accounting Horizons, 8(2), 25-43.

Rumelt, R. P. (1991). How much does industry matter? Strategic Management Journal, 12(3), 167-185.

Said, A. A., HassabElnaby, H. R., \& Wier, B. (2003). An empirical investigation of the performance consequences of nonfinancial measures. Journal of Management Accounting Research, 15, 193-223.

Schmalensee, R. (1985). Do markets differ much? American Economic Review, 75(3), 341-351.

Shyu, Z. J., \& Chiu, Y. C. (2002). Innovation policy for developing Taiwan's competitive advantages. RED Management, 32(4), 369-374.

Sohn, M. H., You, T., Lee, S. L., \& Lee, H. (2003). Corporate strategies, environmental forces, and performance measures: A weighting decision support system using the k-nearest neighbor technique. Expert Systems with Applications, 25(3), 279-292.

Tseng, C. Y., \& Goo, Y. J. J. (2005). Intellectual capital and corporate value in an emerging economy: Empirical study of Taiwanese manufacturers. RED Management, 35(2), 187-201. 
Wang, W. Y., \& Chang, C. (2005). Intellectual capital and performance in causal models: Evidence from the information technology industry in Taiwan. Journal of Intellectual Capital, 6(2), 222-236.

Wu, I. L., \& Chen, J. L. (2006). A hybrid performance measure system for e-business investments in high-tech manufacturing: An empirical study. Information $\mathcal{E}$ Management, 43(3), 364-377.
Wu, S. Y., Hung, S. C., \& Lin, B. W. (2006). Agile strategy adaptation in semiconductor wafer foundries: An example from Taiwan. Technological Forecasting and Social Change, 73(4), 436-451.

Yang, M. C., \& Tung, Y. C. (2006). Using path analysis to examine causal relationships among balanced scorecard performance indicators for general hospitals: The case of a public hospital system in Taiwan. Health Care Management Review, $31(4), 280-288$

Please cite this article in press as: Huang, H.-C. et al., Strategic linkage process and value-driven system: A dynamic analysis of ..., Expert Systems with Applications (2008), doi:10.1016/j.eswa.2008.02.038 